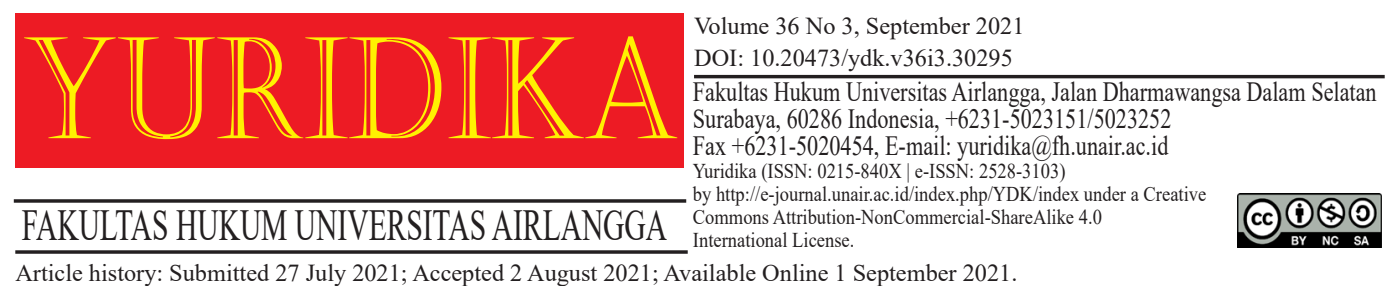

\title{
Reform of Plan Termination in the Suspension of Debt Payment Obligations (PKPU) in Indonesia
}

\author{
Farih Romdoni Putra \\ farihromdoniputra@gmail.com \\ Universitas Indonesia
}

\begin{abstract}
Bankruptcy law exists to ensure justice for creditors and debtors. This research identifies areas of reform in Indonesian bankruptcy law to create justice for creditors and debtors. Specifically, this research focuses on the provisions of the termination of a plan achieved from the suspension of debt payment obligations ('PKPU'). This research used a normative juridical research method with conceptual and comparative approaches. The author examined the bankruptcy law in Indonesia, evaluated several cases of plan termination in PKPU occurring in Indonesia, and later compared the rules in the bankruptcy laws applied in the United States of America (USA), the Netherlands and Singapore. The results of this study indicate that the provisions for plan termination in the bankruptcy law in Indonesia do not protect the debtors' interests. From the termination plan cases in Indonesia, confusion was found in the bankruptcy law, which did not provide legal certainty for both debtors and creditors. Comparing the bankruptcy laws in Indonesia, the USA, the Netherlands and Singapore shows that the Indonesian bankruptcy law needs reform to create flexibility to implement the plan. These findings are discussed further in this article.
\end{abstract}

Keywords: PKPU; Plan Termination; Bankruptcy Law.

\section{Introduction}

The suspension of debt payment obligations ('PKPU') has been an instrument in property law since colonial times. PKPU is a period given by law through a commercial judge's decision to creditors and debtors to discuss ways of paying all or part of their debts with a payment plan, including restructuring if necessary. ${ }^{1}$ PKPU aims to prevent the bankruptcy of debtors who are unable to pay their debts at that time due to liquidity problems but are able to pay their debts in the near future. It provides temporary relief or breathing space in dealing with creditors to 
reorganise and continue their efforts to pay their debts to creditors. ${ }^{2}$

Ironically, even though its purpose is to prevent bankruptcy, PKPU in Indonesia carries a high risk because it can end in bankruptcy. ${ }^{3}$ Secured creditors have the right to vote to approve or reject the plan. In fact, secured creditors do not need to release their secured rights to get voting rights. ${ }^{4}$ In contrast to the bankruptcy process, secured creditors cannot vote on the plan proposed in the bankruptcy process unless they relinquish their secured rights before the vote is held. ${ }^{5}$

The binding power of a confirmed plan achieved in the PKPU process differs from that achieved in the bankruptcy process. Confirmed plans in the bankruptcy proceedings only apply to unsecured creditors, with no exceptions, whether they have filed a claim or not. ${ }^{6}$ This means the plan does not bind the secured creditors. It differs from the confirmed plan in the PKPU process, which applies to all creditors (both secured and unsecured) except for secured creditors who participate in the PKPU process and reject the proposed plan. ${ }^{7}$

Moreover, secured creditors who reject the proposed plan are compensated with the lowest value between the collateral value or the actual value of the loan, which is directly secured by the collateral right on the property. The mechanism of compensation to secured creditors who reject the proposed plan as stipulated in article 281 paragraph (2) of Law No 37/2004 is unclear. Wijaya explained that Law No 37/2004 does not regulate who will supervise the provision of compensation and when the compensation will be paid. ${ }^{8}$ Law No 37/2004 does not even regulate the legal consequences for the debtor who does not provide such compensation.

\footnotetext{
${ }^{2}$ Jerry Hoff, Undang-Undang Kepailitan Di Indonesia (Tatanusa 2000).[187].

${ }^{3}$ Harun Hajadi, 'Permasalahan Negosiasi untuk Penundaan Pembayaran antara Kreditur dan Debitur dalam Kaitannya dengan Implementasi Undang-undang Kepailitan'; Rudhy A Lontoh and others (eds), Penyelesaian Utang-Piutang Melalui Pailit Atau Penundaan Kewajiban Pembayaran Utang (Alumni 2021).[269].

${ }^{4}$ Undang-undang Nomor 37 Tahun 2004 tentang Kepailitan dan Penundaan Kewajiban Pembayaran Utang Ps 281 (1).

5 ibid.[Ps 149].

${ }^{6}$ ibid.[Ps 162].

7 ibid.[Ps 286]. PKPU'.

${ }^{8}$ Aji Wijaya, 'Regulasi Penyelesaian Utang: AKPI Usulkan Perubahan UU Kepailitan \&
} 
This research focuses on the right of creditors to file the plan termination petition. Law No 37/2004 allows creditors to file the plan termination petition if the debtor fails to implement the plan that the Commercial Court has confirmed. ${ }^{9}$ However, the criteria for the number of creditors and the amount of debt for plan termination are not regulated in Law No 37/2004. For example, in the plan termination case filed by PT Bank Mandiri (Persero) Tbk against PT Dwi Aneka Jaya Kemasindo Tbk, the petition to terminate the plan was granted by the Central Jakarta Commercial Court even though only one creditor submitted it. It was known that PT Dwi Aneka Jaya Kemasindo Tbk had paid debts to other creditors. ${ }^{10}$ This means that a plan termination petition can be submitted regardless of the number of creditors and claims.

Given the problems above, this research aimed at designing a reform of the plan termination petition in PKPU in Indonesia. Hopefully, this reform will provide more effective regulations and fairer legal protection for creditors and debtors. As a result, no more parties will be disadvantaged by the loopholes in the existing regulations. Moreover, this study is important because bankruptcy law significantly impacts the economic sector. ${ }^{11}$

This study used the normative juridical research method. This research method is often referred to as doctrinal legal research, which is legal research based on or referring to the implementation of legal norms or norms contained in statutory regulations or positive law. ${ }^{12}$ The results of research that use a normative juridical approach will be prescriptive. ${ }^{13}$

\footnotetext{
${ }^{9}$ Undang-undang Nomor 37 Tahun 2004 tentang Kepailitan dan Penundaan Kewajiban Pembayaran Utang (n 4).[Ps 170 dan 291].

${ }^{10}$ Deliana Pradhita Sari, 'BMRI: Kepailitan DAJK Jadi Jalan Satu-Satunya' (Kabar 24, 2017) $<$ https://kabar24.bisnis.com/read/20171116/16/709860/bmri-kepailitan-dajk-jadi-jalan-satu-satunya $>$ accessed 8 October 2020 .

${ }^{11}$ Kartik B Athreya, 'Welfare Implications of the Bankruptcy Reform Act of 1999' (2002) 49 Journal of Monetary Economics.[1567-1595].

${ }^{12}$ Johnny Ibrahim, Teori Dan Metodologi Penelitian Hukum Normatif (Bayumedia 2007) .[295].

${ }^{13}$ Theresia A Christiani, 'Normative and Empirical Research Methods: Their Usefulness and Relevance in the Study of Law as an Object' (2016) 219 Procedia - Social and Behavioral Sciences. [201-207].
} 
Furthermore, this study used a conceptual approach. The conceptual approach derives from the views and doctrines developed in jurisprudence. ${ }^{14}$ By studying the views and doctrines in jurisprudence, the author figures ideas about legal notions, legal concepts and legal principles relevant to the issues at hand.

This study also used a comparative approach to formulate the reform. A comparative study aims to convey information consisting of two or more different factual contexts; examine the benefits and disadvantages from a comparative perspective; or compare and contrast views, ideas, values, concepts, rules, principles, theories, or other conditions related to the law and the institution. This study aims to improve and advance the law so it can work more effectively. ${ }^{15}$ Comparisons are made to analyse how other legal systems deal with certain legal problems. $^{16}$

This study compared the PKPU regulations in Indonesia with the reorganisation rules in the United States of America (USA) as stipulated in chapter 11 of the US Bankruptcy Code ('US Bankruptcy Code'). The USA was chosen because its bankruptcy law is considered fair to debtors. Debtors are given the opportunity to a fresh start. It is also fair to creditors who share in debt repayment ${ }^{17}$ Comparisons were also made to the bankruptcy laws in the Netherlands and Singapore. Dutch bankruptcy law remained in effect in Indonesia until 1998. Singapore adopted provisions of the US Bankruptcy Code into its bankruptcy laws in 2017.

The research data consisted of statutory regulations and court decisions. Therefore, the author conducted qualitative data analysis to find descriptions of the main ideas in the data. ${ }^{18}$ Using qualitative analysis made it possible to obtain an overview of what happens in the regulation or implementation of a policy.

\footnotetext{
${ }^{14}$ Peter Mahmud Marzuki, Penelitian Hukum (Kencana 2011).[95].

${ }^{15}$ Anwarul Yaqin, 'Legal Research and Writing' [2008] Malayan Law Journal.[19].

${ }^{16}$ David J Gerber, 'Globalization and Legal Knowledge: Implication for Comparative Law' (2001) 75 Tulane Law Review.[969].

${ }^{17}$ Otto E F Lobo, World Insolvency Systems: A Comparative Study (Carswell 2009) 693.

${ }^{18}$ John W Creswell, Research Design: Qualitative, Quantitative and Mixed Methods Approaches (4th edn, Sage Publication 2014).
} 


\section{Plan Termination in PKPU Does Not Protect the Interests of the Debtor}

Law No 37/2004 protects creditors by regulating the plan termination petitions. ${ }^{19}$ However, it does not distinguish between the termination of the plan arising from bankruptcy proceedings and PKPU proceedings. Article 291 of Law No 37/2004 explains that the provisions in article 170 of Law No 37/2004 apply mutatis mutandis to the plan termination in PKPU. Article 170 of Law No 37/2004 regulates the plan termination as follows:

(1) Creditors could file a plan termination petition if the debtors fail to implement the terms of the plan;

(2) The debtor shall prove that the plan has been implemented;

(3) The court may give a moratorium to the debtor no later than 30 (thirty) days after the order of moratorium.

In the author's opinion, Law No 37/2004 provides loose conditions for plan termination. First, Law No 37/2004 does not state how many creditors or claims are required to apply for plan termination. Thus, a debtor who does not fulfil his obligations to only one creditor will be threatened with plan termination - leading to the debtor's bankruptcy. The absence of a requirement for the number of creditors or claims needed to terminate the plan does indeed protect minority creditors who are potentially not prioritised by debtors with bad faith. In this case, good faith is a reasonable consideration for valuing the protection of debtors ${ }^{20}$ Thus, the debtor is expected to carry out all obligations by the confirmed plan.

However, the loose conditions to terminate the plan means the business continuity principle is not implemented holistically in Law No 37/2004. Nugroho argues that the principle of business continuity means that only debtors who are unable to pay their debts to the majority of creditors should be bankrupt. ${ }^{21}$ Thus, the

\footnotetext{
${ }^{19}$ Undang-undang Nomor 37 Tahun 2004 tentang Kepailitan dan Penundaan Kewajiban Pembayaran Utang (n 4).[Ps 291].

${ }^{20}$ Mulyani Zulaeha and others, 'Initiating Comprehensive Verification System in the Settlement of Bankruptcy in Commercial Court' (2016) 48 Journal of Law, Policy and Globalization. [197].

${ }^{21}$ Susanti Adi Nugroho, Hukum Kepailitan Di Indonesia: Dalam Teori Dan Praktik Serta Penerapan Hukumnya (Kencana 2018).[40].
} 
absence of a threshold for plan termination petition could lead to the bankruptcy of debtors who are still able to make payments to most creditors.

In this way, Law No 37/2004 gives room to the parties to determine additional conditions for creditors to terminate the plan. However, the additional conditions for plan termination by the parties create uncertainty for both the debtor's and the creditor's protection. On the other hand, this additional condition is made when the debtor faces the threat of bankruptcy if the creditors do not approve the plan. It shows the debtor's vulnerable position.

Next, one of the alternatives that the debtor can take is when the plan contains provisions of postponement or amendment. Normatively, Law No $37 / 2004$ does not regulate the matter of postponement or amendment of the confirmed plan. This means the debtor is expected to ensure the debt payments since the proposal of the plan. In other words, the debtor must be able to anticipate all future circumstances that might hinder the implementation of the plan and accommodate them into the proposed plan. If the debtor fails to anticipate these conditions, the debtor may not be able to implement the plan. Failure to implement can lead to the plan termination filed by creditors who do not receive payments from the debtor.

The failure to regulate the postponement or amendments of the plan threatens debtors with good faith who are likely to face extraordinary circumstances they never predicted. ${ }^{22}$ Furthermore, Law No 37/2004 does not provide an opportunity for settlement other than the confirmed plan. This means that Law No 37/2004 gives no room for debtors to restructure their debts after the confirmed plan. Law No 37/2004 also does not allow debtors to seek alternative methods of payment to creditors other than the confirmed plan.

In these ways, the debtor has little room to implement the plan because it is overshadowed by the threat of bankruptcy due to the plan termination.

${ }^{22}$ Harold F Lusk, Business Law: Principles and Cases (Richard D Irwin 1986).[1076-1077]. 


\section{The Implementation of Plan Termination Provisions by the Commercial Court The Arpeni Pratama Ocean Line ('APOL') Case}

The APOL case discusses how the clauses in the plan relate to Law No 37/2004. The APOL case began with the filing of the first plan termination petition by PT Asuransi Central Asia ('ACA') as one of PT APOL's creditors. ${ }^{23}$ Since the plan was confirmed, PT APOL had paid 13 interest instalments to ACA from 2012 to 2014. However, PT APOL was negligent in paying the interest instalments due on 30 March 2015.

ACA filed a petition to terminate the plan, but the Commercial Court at the Central Jakarta District Court rejected the petition through Decision No 07/ Pdt. Sus/Pembatalan Perdamaian/2015/PN Niaga Jkt Pusat on 23 July 2015. The court considered that PT APOL had sent notifications since November 2014 to submit a restructuring proposal to the ACA to comply with article 2.6, which regulates the issue of the plan amendment. The court also considered that PT APOL had corresponded with ACA regarding the notification of failure to pay interest instalments for the period 1 March 2015-1 May 2015 and would provide restructuring terms. Thus, the judges rejected the request to terminate the plan because PT APOL had good faith in carrying out the plan's terms. Moreover, the court considered that no other creditor apart from ACA had tried to terminate the plan. After this decision, ACA filed a cassation action on 30 July 2015 that the Supreme Court rejected. ${ }^{24}$

A second termination petition was submitted by CIMB Bank on 18 March 2019 because PT APOL repeatedly neglected to pay both interest and principal debt instalments. In this case, CIMB Bank questioned (i) the payment delays because PT APOL plans to amend the confirmed plan and (ii) the plan amendment process that is not followed by CIMB Bank but still binds it. ${ }^{25}$

\footnotetext{
${ }^{23}$ Pengadilan Negeri Jakarta Pusat, Putusan No 07/Pdt Sus/Pembatalan Perdamaian/2015/ PN Niaga Jkt Pst (2015).

${ }^{24}$ Mahkamah Agung RI, Putusan No 552 K/Pdt Sus Pailit/2015 (2015).

${ }^{25}$ Pengadilan Negeri Jakarta Pusat, Putusan No 04/Pdt Sus Pembatalan Perdamaian/2019/ PN Niaga Jkt Pst (2019).
} 
The Commercial Court rejected the plan termination because the process of amending the plan had been carried out according to the plan. With the amendment to the plan, the court agreed that the share conversion carried out by PT APOL for its debt to CIMB Bank was valid. Furthermore, the court also considered that article 2.6 of the plan dated 1 November 2011 did not contradict article 285 paragraph (2) letter b of Law No 37/2004 so that it was considered a lawful cause.

CIMB Bank also filed a cassation legal action that the Supreme Court granted because the Commercial Court had 'negated the Court's decision and replaced it with an agreement made before a Notary between the Respondent / Debtor and Majority Creditors'. The Supreme Court then declared that the amendment to the plan dated 7 February 2019 was invalid and void. Therefore, the settlement of the debt was returned to the plan confirmed by the court, namely the plan dated 1 November 2011. Because PT APOL could not prove it had been fulfilled, the Supreme Court terminated the plan and declared PT APOL bankrupt. ${ }^{26}$

The APOL case exemplifies how Law No 37/2004 does not clearly regulate changes or delays in implementing the plan. The absence of this arrangement resulted in uncertain payment delays experienced by ACA, CIMB Bank and other creditors. On the other hand, the APOL case also strengthens the author's opinion regarding the limitations of Law No 37/2004 to regulate the possibility of amendments to the confirmed plan. In CIMB Bank's appeal, the Supreme Court conclusively prohibited the stipulation of the amendment clause because it was deemed to have caused the implementation of the plan to be insufficiently guaranteed. Thus, Law No 37/2004 requires more complete provisions regarding the implementation of the plan protecting both debtors and creditors.

\section{The Exist Case}

The Exist case began with Kartini and Lina's petition of termination as Petitioners I and II against the plan previously filed by PT Exist Assetindo ('PT

\footnotetext{
${ }^{26}$ Mahkamah Agung RI, Putusan No 718 K/Pdt Sus Pailit/2019 (2019).
} 
Exist') as the Respondent. The request for termination was submitted because PT Exist did not pay several instalments to Kartini and Lina. It had breached the terms of the confirmed plan.

The Commercial Court rejected the petition on the grounds that Kartini and Lina were unsecured creditors who did not agree to the plan, and there were no objections from creditors who approved the plan. Therefore, there was not enough reason to file a termination petition. ${ }^{27}$ Kartini and Lina filed an appeal to the Supreme Court that was rejected on the grounds that:

"Whereas Cassation Petitioners I and II were not Creditors who approved the plan submitted by the Debtor at the voting meeting on June 24th, 2014 which was confirmed by the Panel of Judges on August 15th, 2014, so that the Petitioners could not file a termination of a quo plan. Also, the claims of Petitioner I and Petitioner II are relatively small compared to claims of other creditors". ${ }^{28}$

The petition for the termination in the Exist case provides another perspective of the creditor interests not accommodated by Law No 37/2004. The Commercial Court's and the Supreme Court's decisions that unsecured creditors who do not approve the plan do not have the right to file a plan termination removes the only protection for creditors in implementing the plan. If the debtors have bad faith and then neglect their obligations to their creditors, they will not have any legal remedies to uphold the plan. Unsecured creditors are creditors bound to a confirmed plan, in contrast to refusing secured creditors who will receive compensation for the value of the guarantee. ${ }^{29}$

Furthermore, the Supreme Court's consideration of the relatively small number of claims compared to other creditors' claims shows a perspective that rules out the interests of Kartini and Lina as minority creditors. Such considerations are in line with those of the Commercial Court who considered that there are creditors who approved the plan and did not want it terminated. Therefore, the Exist case

\footnotetext{
${ }^{27}$ Pengadilan Negeri Jakarta Pusat, Putusan No 1/Pdt Sus Pembatalan Perdamaian/2016/PN Niaga Jkt Pst (2016).

${ }^{28}$ Mahkamah Agung RI, Putusan No 554 K/Pdt Sus Pailit/2016 (2016).

${ }^{29}$ Undang-undang Nomor 37 Tahun 2004 tentang Kepailitan dan Penundaan Kewajiban Pembayaran Utang (n 4).[Ps 281 (2)].
} 
exemplifies the lack of regulation in the plan implementation stage, thereby eliminating protection for minority creditors. Law No 37/2004 does not regulate the minimum requirements of claims or the wishes of other creditors to grant a termination petition.

On the other hand, a threshold for submitting a plan termination protects debtors. However, this threshold cannot be simplified as 'big' or 'small', which creates legal uncertainty in its implementation. In line with the previous author's opinion, neglecting some obligations does not necessarily lead to the plan termination and bankruptcy. Hence, appropriate regulation is needed to guide the plan implementation process and protect the interests of creditors and debtors.

\section{The Nusuno Case}

The Nusuno case began with PT Bank Maybank Indonesia, Tbk ('Maybank') filing a petition for plan termination due to PT Nusuno Karya's ('PT Nusuno') breach of its obligations. Maybank sent three warning letters on 4 October 2019, 24 October 2019 and 10 February 2020. PT Nusuno eventually admitted that it was unable to fulfil its obligations due to COVID-19 hitting Indonesia and requested additional time. The Commercial Court granted the request for 30 days. However, PT Nusuno again did not fulfil its obligations despite the moratorium, so the court granted the termination petition and declared PT Nusuno bankrupt. ${ }^{30}$

The Nusuno case exemplifies the implementation of a plan hindered by force majeure, namely COVID-19. Although PT Nusuno failed to make payments since the end of 2019, the Commercial Court considered the impact of COVID-19 in postponing the payment deadline. However, the postponement was only 30 days as stipulated in article 170 paragraph (3) of Law No 37/2004.

The COVID-19 pandemic is still affecting the global economy at this time - and will continue to do so indefinitely. Given these circumstances, the author proposes extending the moratorium provided in article 170 paragraph (2) of Law

\footnotetext{
${ }^{30}$ Pengadilan Negeri Jakarta Pusat, Putusan No 3/Pdt Sus Pembatalan Perdamaian/2020/PN Niaga Jkt Pst (2020).
} 
No 37/2004 because it cannot accommodate force majeure conditions that give uncertainty to the economy and business climate of a country. Bankruptcy law in Indonesia requires more flexible arrangements to suit the individual circumstances of each debtor.

\section{The Harmas Case}

The Harmas case began with the grant of cassation filed by PT Harmas Jalesveva ('PT Harmas') as the debtor for the decision to terminate the plan by the Commercial Court at the Central Jakarta District Court. Previously, Agustin Farida and Farida Soemawidjaja submitted a petition to terminate the plan because even though they had already paid in full, the apartment unit handed over to them contained many defects. It also did not have a certificate of proper function, so the handover could not be completed. Due to the delay, PT Harmas was also obligated to pay fines to Farida and Soemawidjaja. All these obligations were neglected, so the Commercial Court granted the termination petition and declared PT Harmas bankrupt.

The Supreme Court granted the cassation filed by PT Harmas and cancelled the Commercial Court's decision. The cassation decision is based on two considerations. First, the Supreme Court considered that PT Harmas had attempted to fulfil its obligations by inviting Farida and Soemawidjaja to view the purchased apartment unit and filling out the defect list. The Supreme Court also considered that the signing of the Handover Certificate prior to the issuance of the Certificate of Proper Function had become the practice in buying and selling apartment units. In particular, the Supreme Court considered that the plan did not stipulate that the signing of the BAST should be carried out after the Certificate of Proper Function was issued..$^{31}$

The Harmas case exemplifies how disputes arise from the plan implementation. This case shows how the different interpretations of the plan cannot be resolved other than by termination of the plan. Article 170 of Law No 37/2004 only provides

\footnotetext{
${ }^{31}$ Mahkamah Agung RI, Putusan No 963 K/Pdt Sus Pailit/2020 (2020).
} 
for one type of legal issue in implementing the plan that can be filed for legal remedies: if the debtor neglects his obligations. Thus, for cases where the debtor's obligations are not clear enough, such as in the Harmas case, the creditors have no other recourse than to file a plan termination. In the author's opinion, the dispute in the Harmas case should not have led to the plan termination because there was still implementation even though it was considered less than optimal. The Harmas case is proof that other legal remedies that do not lead to bankruptcy are needed to overcome obstacles to implementing the plan.

\section{Limitations of the Plan Implementation in Law No 37/2004}

In the first petition for the plan termination in the APOL case submitted by the ACA, the Commercial Court and the Supreme Court considered how PT APOL's proposal to restructure delayed implementing the plan. In this case, the Commercial Court considered the proposal from PT APOL to conduct debt restructuring in implementing article 2.6 of the Plan. However, in the second petition for the plan termination submitted by CIMB Bank, the Supreme Court considered article 2.6 of the Plan, which regulates amendments to the plan, to contradict the principle of balance. It contributes to the insufficient plan implementation.

The APOL case shows the court's inconsistencies in considering the possibility of the plan amendment. As in the previous discussion, the author argues that the APOL case shows that plan amendment can be a tool to protect debtors from bankruptcy. Although the author disagrees with the terms and clause in article 2.6 of the plan, it is undeniable that PT APOL carried out the restructuring process with approval from the creditors except for CIMB Bank. This means PT APOL and its creditors (except CIMB Bank) had found a solution to PT APOL's debt repayment.

There are two significant lessons from the APOL case. First, the plan amendment should apply to all creditors - not only the approving creditors. Forcing a plan amendment on creditors who refuse gives room for debtor and majority creditors to conspire to create a detrimental-to-minority plan. In an extreme possibility, article 2.6 of the plan even opens room for majority creditors to eliminate PT APOL's 
obligations to other creditors. If this condition should occur, then the Supreme Court's Decision No 718 K/Pdt Sus Pailit/2019 has truly considered the principle of balance in bankruptcy law.

Second, there is a lack of room to restore the debtors' rights during the implementation of the plan. In the APOL case, the postponement and the amendment of the plan should not immediately bankrupt PT APOL. Instead, CIMB Bank could obtain exemptions and make the plan amendment separately so that PT APOL could be saved. The same thing also happened in the Exist case, where an unpaid creditor had no other option than to file a termination petition. On the other hand, judges in the Exist case even prioritised broader interests without providing solutions to unpaid creditors.

Last, the Harmas case shows that the settlement of the plan implementation has no forum other than termination of the plan. Problems arise from different interpretations regarding the plan clause. The cases above show how the lack of solutions provided by Law No 37/2004 is detrimental to debtors and creditors. In this case, the author argues that other solutions are needed, such as payment postponement, plan amendments or even a brief examination to address the problems to achieve an effective and efficient insolvency solution. In this regard, Nocilla argues that an effective and efficient insolvency regime must be able to:

(1) encourage the reorganization of financially distressed debtors, thereby avoiding improvident liquidations that would destroy value;

(2) encourage the liquidation of economically distressed debtors as quickly as practicable, so as to mitigate further losses and permit the redeployment of assets to more productive ends; and

(3) provide mechanisms for easy conversion from reorganization to liquidation proceedings, if the insolvent debtor's circumstances change. ${ }^{32}$

The four cases did not reflect the inclusion of affected persons or the principle of rational planning, as explained by Korobkin. In the APOL case, the exclusion of

${ }^{32}$ Alfonso Nocilla, 'Asset Sales and Secured Creditor Control in Restructuring: A Comparison of the UK, US and Canadian Models' (2017) 26 International Insolvency Review.[64]. 
CIMB Bank or other creditors to amend the plan is directly contrary to the principle of inclusion of affected persons. Korobkin explains the principles of inclusion of affected persons as follows:

"In resolving this concern, the parties in the bankruptcy choice situation would choose a principle which required that each person affected by financial distress have threshold eligibility to press his or her demands in that context. Let us call this the 'principle of inclusion.' The principle of inclusion, it should be emphasized, does not speak at all to which particular demands should ultimately be recognized and which should be denied. It provides only that no persons should be disqualified from pursuing their aims merely by virtue of the position that they occupy". ${ }^{33}$

In addition, there is a conflict with the principle of rational planning in which the Supreme Court stated that a plan amendment was not possible. Korobkin describes the principle of rational planning as 'A bankruptcy system committed to the principle of rational planning would include whatever mechanisms are necessary to achieve its ultimate object of realising the most rational long-term plan' ${ }^{34}$

Furthermore, in discussing further corporate reorganisation in the US Bankruptcy Code, Korobkin explains:

"A bankruptcy system founded on the principle of rational planning has resources to guide the critical decision of whether to reorganize or liquidate. Consistent with the principle of rational planning, the Bankruptcy Code recognizes the limited role of corporate reorganization and, at least in principle, regulates the use of reorganization to achieve the most rational outcome. It does not mandate a set solution for predefined circumstances, nor does it impose a reductive standard-such as an insolvency test or any other economic measure to determine the proper path for the business. Instead, the Code generally authorizes the managers or owners of the corporation, or a group of its creditors, to initiate either reorganization or liquidation cases. It then subjects their decision to possible review and, based on the rational considerations that emerge from particular circumstances, possible revision". ${ }^{35}$

Korobkin indirectly agrees to the changes of options the parties can make, both liquidation and reorganisation. If the parties are to realise more rational long-term

${ }^{33}$ Donald R Korobkin, 'Contractarianism and the Normative Foundations of Bankruptcy Law’ (1993) 71 Texas Law Review.[575].

${ }^{34}$ ibid. [595].

${ }^{35}$ ibid. 
planning, the bankruptcy law should open up space so they can amend the plan to protect their respective interests. If the parties cannot amend the plan, they will no longer be able to adjust the plan to the various conditions experienced by the debtor. To straighten this out, Law No 37/2004 should accommodate provisions that could adapt the plan to the needs of debtors and creditors at the time of its discussion and implementation.

\section{Reform of Plan Termination in PKPU: Lessons from the Netherlands, Singapore and the United States of America}

The implementation of the plan that could lead to a debtor's bankruptcy is related to (i) the amendment of the plan and (ii) plan termination. In this discussion, the author compared the provisions for plan termination in Indonesia to (i) the provisions of surseance van betaling in the Dutch Bankruptcy Act (Faillissementswet), Staatsblad of 1893 No 140 as last amended by Staatsblad of 2020 No 414 ('Dutch Bankruptcy Act'); (ii) the provisions of the scheme of arrangement and judicial management in the Singapore Insolvency, Restructuring and Dissolution Act, Act No 40/2018 as amended by Act No 39/2020 ('Singapore Insolvency Act'); and (iii) the reorganisation provisions in the US Bankruptcy Code.

Legal remedies in each instrument have different filing grounds and legal consequences for the debtor. Surseance van betaling, similar to the PKPU in Law No 37/2004, allows creditors to file a termination of the plan once the debtor fails to carry out its obligations. Meanwhile, when the plan is terminated, the debtor will be declared bankrupt. ${ }^{36}$ Unlike surseance van betaling, the scheme of arrangement in Singapore gives the court broader powers to determine the legal consequences arising from a review of a confirmed plan. A review of the confirmed plan can be submitted if a debtor or scheme of arrangement manager takes action, ignores or makes a decision that violates the restructuring plan's terms. The court has the power to reverse the action that has been taken or enter an order it deems appropriate to correct the action, neglect or decision of the debtor. ${ }^{37}$

\footnotetext{
${ }^{36}$ Dutch Bankruptcy Act s 280 jo ss $165-166$.

${ }^{37}$ Singapore Insolvency Act s 72(2).
} 
The US Bankruptcy Code also allows the revocation of the plan confirmation if the confirmation is based on fraud and must be filed within 180 days of the confirmation. The legal effect of the termination allows conversion from chapter 11 to chapter 7 (liquidation) if requested by creditors. ${ }^{38}$ In addition, conversion from chapter 11 to chapter 7 can be submitted by the creditor if there is proof that the debtor committed a material default against the confirmed plan. This means that not all defaults of the plan result in the liquidation of the debtor. ${ }^{39}$ Furthermore, chapter 11 explicitly regulates that the plan could be modified at any time after confirmation of such plan before substantial consummation. ${ }^{40}$ Meanwhile, from other restructuring instruments, there is no provision whether the amendment or modification of a plan could be regulated by each plan casuistically.

Apart from chapter 11, the judicial management provisions in the Singapore Insolvency Act also give the judicial manager the authority to carry out amendments to a plan approved by creditors. ${ }^{41}$ The judicial manager can even make modifications without obtaining approval from creditors as long as the modifications are not substantial. However, if they are substantial, the judicial manager will hold a creditor meeting to vote on the modifications. ${ }^{42}$ In this meeting, creditors can propose to modify the plan with the approval of the judicial manager. ${ }^{43}$

The existence of instruments of plan termination and amendment are dichotomous and contradictory. Debtors who face obstacles in carrying out their obligations face two options: to amend the plan to suit their abilities or end the restructuring. As for the comparison of the countries above, two things can be done to meet the dichotomy.

First, failure to implement the plan does not necessarily lead to an end of the restructuring, especially bankruptcy or liquidation. Based on the judicial management applied in Singapore, bankruptcy law can give broader powers to the

\footnotetext{
${ }^{38}$ US Bankruptcy Code s 1144.

${ }^{39}$ ibid. s 1112(b)(4).

${ }^{40}$ ibid. s $1127(\mathrm{~b})$.

${ }^{41}$ Singapore Insolvency Act s 110(1).

${ }^{42}$ ibid. s $110(2)$.

${ }^{43}$ ibid. s 110(4).
} 
court to determine actions that are more favourable to the parties, whether requested or not. ${ }^{44}$ The alternatives of legal consequences other than bankruptcy can be used in certain situations where creditors will be more disadvantaged by the end of the restructuring. However, it is undeniable that there is a need for provisions that allow the termination of restructuring in certain circumstances in which the debtor can no longer continue the business. Yet, ending the restructuring does not necessarily have to be followed by bankruptcy. This aims to reinforce the boundaries between bankruptcy and restructuring. If the debtor breaches the plan, the judge needs to consider whether the breach is material or not - the same as chapter 11. This means that the late debt payment by the debtor is only a trigger to further investigate the sustainability of the plan, not to terminate it.

In the APOL case, the provisions regarding the conditions for bankruptcy after the plan confirmation at the statutory level will provide certainty for creditors. In this case, PT APOL was only able to obtain the approval of most creditors after years of negotiations and meetings. This situation can be prevented if Law No 37/2004 limits what can be amended from the plan and whether there are conditions to amend or postpone the plan. With this provision, creditors will receive protection from the uncertainty of plan implementation. The flexibility of plan implementation is in line with the rational planning principle explained by Korobkin. This principle does not describe one solution for each situation; instead, there needs to be an adjustment for each situation, which can change at any time.

Second, there needs to be a provision to amend or modify the confirmed plan. Although it cannot be equated per se, amendments of the plan in judicial management in Singapore provide ample room for the judicial manager to be able to adjust the plan to the debtor. Moreover, creditors are still given protection if the amendments are substantial. In this case, Law No 37/2004 can adopt a similar approach whereby amendments to the confirmed plan could be carried out with the approval of its creditors or by a court decision.

${ }^{44}$ ibid. s $110(1)$. 
Amendments made in laws and regulations - such as those proposed in this research - will impact debtors and creditors. For example, the enactment of the Bankruptcy Reform Act of 1978 in the USA resulted in higher contract interest rates because it affected the cost of producing loans for financial intermediaries. ${ }^{45}$ However, an important element for debtors that has a big influence on the company's success to rise again, according to the new rules of the US Bankruptcy Code, is the ability to obtain additional financing during the restructuring period. ${ }^{46}$ However, the reform proposed in this research is supposed to provide legal certainty for creditors and debtors so that both parties receive adequate protection.

\section{Plan Termination in UNCITRAL Legislative Guide on Insolvency Law}

The aim of the United Nations Commission on International Trade Law ('UNCITRAL') compiling the Legislative Guide on Insolvency Law ('UNCITRAL Guidelines') is to help establish an efficient and effective legal framework when a debtor experiences financial difficulties. Hopefully, the UNCITRAL guidelines can be used as a reference for countries in drafting new laws or amending existing laws. The UNCITRAL Guidelines try to strike a balance between a debtor in financial difficulties and the interests of other parties who are affected by the debtor's condition. Singapore is one of the countries that has adopted the UNCITRAL Guidelines to establish the Insolvency, Restructuring, and Dissolution Act. Furthermore, this research discusses how the UNCITRAL Guidelines regulate the plan termination.

The UNCITRAL Guidelines provide recommendations that the failure of plan implementation does not necessarily end in bankruptcy. The court is given the power or discretion to determine this. In fact, in its recommendations, the court may only turn reorganisation into bankruptcy if the debtor's failure to implement

\footnotetext{
${ }^{45}$ Emmanuel Alanis and Margot Quijano, 'Investment-Cash Flow Sensitivity and the Bankruptcy Reform Act of 1978' (48AD) 2019 The North American Journal of Economics and Finance.[119-140].

${ }^{46}$ Kartick Gupta and Chandrasekhar Krishnamurti, 'Does Corporate Social Responsibility Engagement Benefit Distressed Firms? The Role of Moral and Exchange Capital' (2018) 50 PacificBasin Finance Journal.[249-262].
} 
the plan is a failure of a substantial nature. ${ }^{47}$ The court must first assess whether or not the debtor's failure is substantial before conversing the process to bankruptcy. As for the failures in plan implementation, the UNCITRAL Guidelines provide the following recommendations: "The insolvency law may specify that where there is a substantial breach by the debtor of the terms of the plan or an inability to implement the plan, the court may close the judicial proceedings and parties in interest may exercise their rights at law'. ${ }^{48}$

The UNCITRAL Guidelines thus emphasise options other than bankruptcy if the debtor could not implement the plan. The creditors can exercise their rights at law, such as by filing a civil suit or executing the guarantees. Thus, the UNCITRAL Guidelines are in accordance with the author's proposal so that violations of the confirmed plan do not automatically lead to bankruptcy.

The UNCITRAL Guidelines also provide views on the amendment to the confirmed plan. An amendment can be made if the debtor cannot implement the terms of the plan. Several provisions on insolvency laws stipulate that plan can only be amended if the amendments are made while protecting the interests of creditors. Other provisions stipulate that amendments to the plan can be carried out if the condition required to do so and the amended plan is in accordance with applicable provisions, such as the plan's terms, creditors' classes and notification to creditors. ${ }^{49}$

Based on this view, the UNCITRAL Guidelines provide the following recommendations:

1) The insolvency law should permit amendment of a plan and specify the parties that may propose amendments and the time at which the plan may be amended, including between submission and approval, approval and confirmation, after confirmation and during implementation, where the proceedings remain open.

2) The insolvency law should establish the mechanism for approval of amendments to

\footnotetext{
${ }^{47}$ United Nations Commission on International Trade Law, Legislative Guide on Insolvency Law Parts One and Two (United Nations Publication 2005).[238].

48 ibid.

${ }^{49}$ ibid.[230].
} 
a plan that has been approved by creditors. That mechanism should require notice to be given to the creditors and other parties affected by the proposed modification; specify the party required to give notice; require the approval of creditors and other parties affected by the modification; and require the rules for confirmation (where confirmation is required) to be satisfied. The insolvency law should also specify the consequences of failure to secure approval of proposed amendments. ${ }^{50}$

The above recommendations are in line with the author's suggestion that Law No 37/2004 can give the opportunity to amend the confirmed plan as long as it has the approval of its creditors. Hopefully, this amendment will provide adequate protection for debtors who are currently vulnerable to bankruptcy for breaching the terms of the plan. It also protects creditors who want the debtor's business to continue for the sake of repayment of their debts.

\section{Conclusion}

Law No 37/2004 still contains weaknesses in providing protection, especially to debtors, regarding the provisions of termination of the plan achieved in the process of PKPU. The law provides little narrow room for parties, particularly debtors, to amend or modify the confirmed plan. However, there are possible ways to change the position and interests of both creditors and debtors.

The results of comparisons to other countries do not provide a united trend regarding termination and amendment of a confirmed plan. This considers the dichotomy between plan amendment and termination. In the author's opinion, negligence in implementing the plan should not always lead to the end of restructuring or bankruptcy. Instead, bankruptcy law should give more room so that the parties and the court can determine the best way to maximise the goals and interests of all existing parties. This can be done by giving the opportunity to amend a confirmed plan. This research shows how policymakers can help make room for the equal protection of debtors and creditors.

${ }^{50}$ ibid.[237]. 


\section{Bibliography}

Alanis E and Quijano M, 'Investment-Cash Flow Sensitivity and the Bankruptcy Reform Act of 1978' (48AD) 2019 The North American Journal of Economics and Finance.

Athreya KB, 'Welfare Implications of the Bankruptcy Reform Act of 1999' (2002) 49 Journal of Monetary Economics.

Christiani RA, 'Normative and Empirical Research Methods: Their Usefulness and Relevance in the Study of Law as an Object' (2016) 219 Procedia - Social and Behavioral Sciences.

Creswell JW, Research Design: Qualitative, Quantitative and Mixed Methods Approaches (4th edn, Sage Publication 2014).

Fuady M, Hukum Pailit 1998: Dalam Teori Dan Praktek (Citra Aditya Bakti 2002).

Gerber DJ, 'Globalization and Legal Knowledge: Implication for Comparative Law’ (2001) 75 Tulane Law Review.

Gupta K and Krishnamurti C, 'Does Corporate Social Responsibility Engagement Benefit Distressed Firms? The Role of Moral and Exchange Capital' (2018) 50 Pacific-Basin Finance Journal.

Hoff J, Undang-Undang Kepailitan Di Indonesia (Tatanusa 2000).

Ibrahim J, Teori Dan Metodologi Penelitian Hukum Normatif(Bayumedia 2007).

Korobkin DR, 'Contractarianism and the Normative Foundations of Bankruptcy Law’ (1993) 71 Texas Law Review.

Lobo OEF, World Insolvency Systems: A Comparative Study (Carswell 2009).

Lontoh RA and others (ed), Penyelesaian Utang-Piutang Melalui Pailit Atau Penundaan Kewajiban Pembayaran Utang (Alumni 2021).

Lusk HF, Business Law: Principles and Cases (Richard D Irwin 1986).

Mahkamah Agung RI, Putusan No 552 K/Pdt Sus Pailit/2015 (2015).

Mahkamah Agung RI, Putusan No 554 K/Pdt Sus Pailit/2016 (2016).

Mahkamah Agung RI, Putusan No 718 K/Pdt Sus Pailit/2019 (2019). 
Mahkamah Agung RI, Putusan No 963 K/Pdt Sus Pailit/2020 (2020).

Marzuki PM, Penelitian Hukum (Kencana 2011).

Nocilla A, 'Asset Sales and Secured Creditor Control in Restructuring: A Comparison of the UK, US and Canadian Models' (2017) 26 International Insolvency Review.

Nugroho SA, Hukum Kepailitan Di Indonesia: Dalam Teori Dan Praktik Serta Penerapan Hukumnya (Kencana 2018).

Pengadilan Negeri Jakarta Pusat, Putusan No 07/Pdt Sus Pembatalan Perdamaian/2015/PN Niaga Jkt Pst (2015).

Pengadilan Negeri Jakarta Pusat, Putusan No 1/Pdt Sus Pembatalan Perdamaian/2016/PN Niaga Jkt Pst (2016).

Pengadilan Negeri Jakarta Pusat, Putusan No 04/Pdt Sus Pembatalan Perdamaian/2019/PN Niaga Jkt Pst (2019).

Pengadilan Negeri Jakarta Pusat, Putusan No 3/Pdt Sus Pembatalan Perdamaian/2020/PN Niaga Jkt Pst (2020).

Sari DP, 'BMRI: Kepailitan DAJK Jadi Jalan Satu-Satunya' (Kabar 24, 2017) $<$ https://kabar24.bisnis.com/read/20171116/16/709860/bmri-kepailitan-dajkjadi-jalan-satu-satunya $>$ accessed 8 October 2020.

Undang-undang Nomor 37 Tahun 2004 tentang Kepailitan dan Penundaan Kewajiban Pembayaran Utang.

United Nations Commission on International Trade Law, Legislative Guide on Insolvency Law Parts One and Two (United Nations Publication 2005).

Wijaya A, 'Regulasi Penyelesaian Utang: AKPI Usulkan Perubahan UU Kepailitan $\&$ PKPU'.

Yaqin A, 'Legal Research and Writing' [2008] Malayan Law Journal.

Zulaeha $\mathrm{M}$ and others, 'Initiating Comprehensive Verification System in the Settlement of Bankruptcy in Commercial Court' (2016) 48 Journal of Law, Policy and Globalization.

HOW TO CITE: Farih Romdoni Putra, 'Reform of Plan Termination in the Suspension of Debt Payment Obligations (PKPU) in Indonesia' (2021) 36 Yuridika. 